\title{
ANALISIS KEANEKARAGAMAN DAN KEMELIMPAHAN RELATIF ALGAE MIKROSKOPIS DI BERBAGAI EKOSISTEM PADA KAWASAN INTERTIDAL PULAU MENJANGAN BALI BARAT
}

\author{
Gede Ari Yudasmara \\ Jurusan Budidaya Kelautan, Universitas Pendidikan Ganesha, \\ Singaraja-Bali
}

Email: ariyudasmara@gmail.com

\begin{abstract}
Abstrak
Algae mikroskopis memiliki peranan yang penting karena merupakan organisme autotrof yaitu organisme yang mampu menghasilkan makanan sendiri, sehingga berperan sebagai produsen bagi konsumen yang hidup di lautan dan sangat erat kaitannya dengan rantai makanan. Tujuan dari penelitian ini adalah mengetahui keanekaragaman dan kemelimpahan relatif algae mikroskopis serta tingkat perbedaannya pada ekosistem Padang Lamun, Terumbu Karang dan Mangrove di kawasan intertidal PulauMenjangan Bali Barat. Penelitian ini termasuk penelitian deskriptif eksploratif dengan metode observasi lapangan. Populasi dari penelitian ini adalah seluruh algae mikroskopis pada ekosistem Mangrove, Padang Lamun dan Terumbu Karang, sedangkan Sampel dalam penelitian ini adalah algae mikroskopis yang berhasil ditangkap pada sejumlah titik pengambilan sampel. Analisis data menggunakan statistic ekologi. Hasil penelitian menunjukkan (1) algae mikroskopis yang teridentifikasi pada ekosistem Mangrove sebanyak 20 jenis, ekosistem Padang Lamun 24 jenis, dan ekosistem Terumbu Karang 32 jenis; (2) Indeks keanekaragaman pada ekosistem Mangrove dan Padang Lamun tergolong sedang sedangkan ekosistem Terumbu Karang tergolong tinggi; (3) Kemelimpahan relative tertinggi pada Lamun adalah spesies Guinardiablavyana, ekosistem Mangrove adalah Triceratiumalternans dan ekosistem Terumbu karang adalah Cocconeisscutelum; (4) terdapat perbedaan keanekaragaman dan kemelimpahan relatif algae mikroskopis antara ketiga ekosistem di kawasan intertidal Pulau Menjangan.
\end{abstract}

Kata kunci: algae mikroskopis, keanekaragaman, kemelimpahan relatif, zona intertidal, Pulau Menjangan

\begin{abstract}
Sea grape (Cauler paracemosa) is amacro green algaeare of tenused as food for people around the coast. But supply is stillinvery limited quantitie sandseasonal, because it still dependson the nature and has not been properly cultivated. It required the cultivationto support continuity of production. This study aims to examine and analyze the effective nessandefficiency of rigidquadrantnets made from bamboo incultivation of Cauler paracemosa and assess the quality and
\end{abstract}


quantity btained from the application of rigid quadrant nets made of bamboo in the cultivation of Caulerparacemosa. To achievethese goal sthrough research experiments conducted by the draftpre-testpost-testcontrol group design. The results showed that the rigidquadrantnets made of bamboo is quite effective and efficientin the cultivation of Caulerpa racemosa, norin terms of quality and quantity of the quadrant rigidsubstrate made of bamboo nets good enough quality and yieldas much aslwas 2340.46grams replay, replayll of 2003, the 60 grams and repeat Illwas 2135.5 grams withthe planting periodfor 42 days.

Keywords: aquaculture, Caulerparacemosa, bamboo media

\section{PENDAHULUAN}

Zona intertidal merupakan zona yang dipengaruhi oleh pasang surut air laut dengan luas area yang sempit antara daerah pasang tertinggi dan surut terendah. Pada zona ini terdapat variasi factor lingkungan yang cukup besar seperti fluktuasi suhu, salinitas, kecerahandan lain - lain. Variasi ini dapat terjadi pada daerah yang hanya berjarak sangat dekat saja misalnya beberapa $\mathrm{cm}$. Zona ini dihuni oleh organisme yang keseluruhannya merupakan organisme bahari, salah satunya adalah algae mikroskopis atau lebih dikenal dengan sebutan Fitoplankton.

Fitoplankton memiliki peranan yang paling penting karena berperan sebagaiorganismeautotrofyaitu

organisme yang mampu menghasilkan makanan sendiri. Kemampuan ini disebabkan oleh kandungan klorofil pada fitoplankton, sehingga dengan bantuan cahaya matahari fitoplankton mampu melakukan proses fotosintesis di dalam tubuhnya. Dengan kata lain fitoplankton berperan sebagai produsen bagi konsumen yang hidup di lautan dan sangat erat kaitannya dengan rantai makanan. Secara garis besar fitoplankton dapat dibagi ke dalam empat golongan yaitu Diatom,
Dinoflagelata, Trichodesmium dan Kokolitoforid.

Diatom merupakan golongan terpenting yang mendominasi fitoplankton dan paling banyak ditemukan di laut terutama pada lokasi yang melimpah akan nutrisi. Diatom digolongkan ke dalam kelas Bacillariophyceae, dapat hidup sebagai sel tunggal ataupun berkoloni dengan kemampuan bereproduksi secara seksual maupun aseksual. Golongan satu ini memiliki banyak sekali julukan karena merupakan produsen primer yang sangat berpengaruh terhadap keberlangsungan hidup biota laut lainnya, salah satunya adalah "jewel of the sea". Julukan ini diberikan berdasarkan struktur morfologi dari diatom yakni mengandung silika (struktur utama yang menyusun kaca), dengan berbagai variasi bentuk yang indah. Struktur khas inilah yang membedakan diatom dengan golongan fitoplankton lainnya.

Dinoflagelata digolongkan ke dalam kelas Dinophyceae, merupakan golongan fitoplankton yang umum ditemukan di laut setelah golongan diatom. Dinoflagelata bereproduksi secara aseksual melalui pembelahan sel. Dinding selnya tersusun atas selulosa yang tebal dan kuat sebagai perlindungan sel terhadap lingkungan 
luar. Terdapat ciri khusus pada golongan ini karena memiliki alat gerak berupa bulu cambuk atau flagella dan kandungan pigmen dalam selnya yang sangat spesifik. Selain mengandung klorofil-a dan klorofil-c, juga terdapat pigmen $\quad \beta \quad$ carotene dan xanthophylls sehingga memberikan warna coklat kekuningan.

Golongan ketiga yang banyak dijumpai di lautan adalah Trichodesmium. Nama Trichodesmium berasal dari bahasa Yunani yaitu 'tricho' = rambut dan "desmus" = jalinan. Golongan ini termasuk ke dalam Divisi Cyanobacteria (memiliki kekerabatan dekat dengan bakteri). Sel-selnya tidak memiliki inti sel yang jelas, dan biasanya hidup dengan cara membentuk rantai berupa filament yang mengelompok dalam agregat koloni berbentuk seperti jalinan rambut.

Golongan keempat dari fitoplankton yang umumnya dijumpai adalah Kokolitoforid, yang tergolong dalamkelas Prymnesiophyceae atau Haptophyceae. Warna tubuhnya coklat keemasan dan hidup secara uniselular. Golongan ini memiliki kemampuan untukberfotosintesis dan warna coklat keemasan pada tubuhnya disebabkan oleh kandungan pigmen $\beta$ carotene,fucoxanthin, diadinoxanthin dan diatoxanthine. Ciri khusus yang dimiliki oleh kokolitoforid adalah cocolith pada sel tubuhnya yang bentuknya menyerupai perisai atau sisik sebagai alat proteksi terhadap lingkungan luar. Jika cocolith merupakan pelindungnya, maka sel yang memiliki cocolith disebut dengan kokolitofor.

Fitoplankton banyak dijumpai pada kawasan pesisir yang didominasi atas tiga corak ekosistem yakni ekosistem padang lamun, terumbu karang dan mangrove. Ekosistem padang lamun merupakan suatu ekosistem yang berada diantara kawasan ekosistem mangrove dan terumbu karang. Sama seperti ekosistem lain, dalam ekosistem lamun juga terbentuk rantai makanan (food chain) dimana yang berperan sebagai produsen adalah lamun, alga makrobentos, dan fitoplankton. Sebagai tempat mencari makan bagi beberapa biota laut, padang lamun mengandung material hayati dan non hayati baik yang bersumber dari lamun itu sendiri maupun dari biota-biota laut yang berasosiasi.

Sebagai bagian dari ekosistem laut, ekosistem terumbu karang merupakan ekosistem yang memilikisejumlah kekhasan dan nilai yang penting ditinjau dari sudut ekologi maupun ekonomi. Kekhasan yang dimaksud adalah: 1) ekosistem terumbu karang hanya dijumpai di lautan tropis dan tidak dijumpai di lautan dingin; 2) ekosistem terumbu karang biasanya terdapat pada kedalaman laut yang relatif dangkal yaitu 0-70 meter; 3) ekosistem terumbu karang merupakan ekosistem dengan tingkat keragaman dan produktivitas yang tinggi; dan 4) ekosistem terumbu karang merupakan ekosistem yang penuh dengan biota yang berwarna-warni serta bentuk pertumbuhan yang indah (Nybakken, 1988 dan Nontji, 1986 dalam Swasta, 2010).

Mangrove merupakan kawasan hutan yang tersusun atas komunitas tumbuhan halofit (tanaman yang mampu bertahan hidup di daerah dengan kadar garam tinggi). Hutan mangrove merupakan ekosistem yang umumnya ditemukan di wilayah tropis serta terdiri 
atas berbagai jenis biota yang sangat dipengaruhi oleh faktor-faktor fisik yang ada disekitarnya, antara lain: susunan zat kimia air, aliran dan pergerakan arus serta proses-proses alam yang terjadi di laut. Dilihat dari posisinya, hutan mangrove pada umumnya tumbuh di zone pasang surut pada pantai yang berteluk dengan topografi yang landai (Boaden dan Seed, 1985 dalam Swasta, 2010).

Dalam setiap ekosistem terdapat komponen biotik dan abiotik yang saling berinteraksi satu sama lain, begitu pula pada ekosistem pesisir. Komponen biotik merupakan bagian dari ekosistem yang terdiri dari seluruh tingkatan makhluk yang ada di wilayah ekosistem tersebut seperti tumbuhan, hewan, jamur dan bakteri. Komponen biotik ini akan membentuk suatu hubungan memakan dan dimakan yang disebut dengan rantai makanan. Sedangkan komponen abiotik adalah bagian dari ekosistem yang terdiri atas unsur fisika dan kimia (non-hidup). Unsur fisika dan kimia akan membentuk lingkungan. Lingkungan memegang peranan penting bagi keberlangsungan hidup komponen biotik dalam suatu ekosistem. Faktorfaktor lingkungan yang banyak mempengaruhi kehidupan dalam ekosistem pesisir antara lain: gerakan air, salinitas, suhu, dan cahaya matahari.

Pulau Menjangan merupakan pulau kecil yang terletak di area Taman Nasional Bali Barat yang secara administratif terletak di Kabupaten Jembrana dan Kabupaten Buleleng. Area Pulau Menjangan merupakan kawasan pelestarian yang terdiri dari wilayah daratan dan perairan. Perairan pantainya memiliki tiga corak ekosistem yang saling berkaitan yaitu ekosistem padang lamun, terumbu karang dan hutan bakau (mangrove), yang mana diketiga ekosistem ini terdapat komunitas plankton yang perlu diteliti termasuk komunitas fitoplanktonnya. Permasalahannya adalah hingga saat ini belum ada penelitian yang membandingkan keanekaragaman dan kemelimpahan fitoplankton antara ekosistem padang lamun, terumbu karang dan mangrove di kawasan Pulau Menjangan Bali Barat. Dengan melakukan pendekatan statistik ekologi akan diketahui struktur komunitas fitoplankton yang hidup di kawasan tersebut.

Tujuan dari penelitian ini adalah: (1) mengetahui komposisi spesies fitoplankton yang hidup pada ekosistem padang lamun, terumbu karang dan mangrove di kawasan intertidal Pulau Menjangan Bali Barat; (2) mengidentifikasi besar indeks keanekaragaman fitoplankton yang hidup pada ekosistem padang lamun, terumbu karang dan mangrove di kawasan intertidal Pulau Menjangan Bali Barat; kemelimpahan mengidentifikasi fitoplankton yang hidup pada ekosistem padang lamun, terumbu karang dan mangrove di kawasan intertidal Pulau Menjangan Bali Barat; mengetahuitingkat perbedaan keanekaragaman fitoplankton yang hidup pada ekosistem padang lamun, terumbu karang dan mangrove di kawasan intertidal Pulau Menjangan Bali Barat; (5) mengetahui tingkat perbedaan kemelimpahan fitoplankton yang hidup pada ekosistem padang lamun, terumbu karang dan mangrove di kawasan intertidal Pulau Menjangan Bali Barat. 


\section{METODE}

Penelitian ini termasuk penelitian deskriptif eksploratif. Menggunakan rancangan penelitian lapangan (field study) yang kemudian dilanjutkan dengan kegiatan identifikasi di laboratorium. Pengambilan data dilaksanakan ketika laut dalam keadaan pasang. Lokasi penelitian adalah kawasan intertidal Pulau Menjangan Bali Barat. Pada masing-masing ekosistem tersebut akan ditentukan 15 titik pengambilan sampel dan selanjutnya akan dilakukan identifikasi jenis fitoplankton di Laboratorium Jurusan Pendidikan Biologi Universitas Pendidikan Ganesha.

Metode pengumpulkan data dilakukan melalui observasi lapangan dengan penentuan titik pengambilan sampel dengan membentangkan tali transek. Sampel yang telah diambil kemudian ditampung dan disimpan dalam botol flakon yang telah berisi larutan formalin $4 \%$ sebagai bahan pengawet. Sampel kemudian diidentifikasi dengan bantuan mikroskop, dan identifikasi sampel dilakukan dengan buku identifikasi plankton. Selain itu juga dilakukan pengukuran variabel lingkungan meliputi salinitas, suhu, turbiditas dan $\mathrm{pH}$ yang dilakukan menggunakan Water Quality Checker dan diukur secara langsung pada setiap titik pengambilan sampel.

Analisis data keanekaragaman dan kemelimpahan fitoplankton antara yang hidup di ekosistem padang, lamun, terumbu karang dan mangrove ini dilakukan dengan melakukan pendekatan statistik ekologi untuk mengetahui struktur komunitasnya.

Nilai indeks keanekaragaman fitoplankton dapat dihitung dengan rumus indeks keanekaragaman dari Shanon-Wiener sebagai berikut.

$$
H^{\prime}=-\sum\left(\frac{n i}{N} \ln \frac{n i}{N}\right)
$$

Keterangan :

$\mathrm{H}^{\prime} \quad$ = Indeks diversitas

$\mathrm{Ni}=$ Cacah individu spesies ke-i

$\mathrm{N}=$ Total individu dalam komunitas

Adapun kriteria tentang tingkat keanekaragaman menurut Basmi (1999) dalam Fachrul (2007), sebagai berikut:

$\mathrm{H}^{\prime}<1=$ stabilitas komunitas biota rendah

$1<H^{\prime}<3=$ stabilitas komunitas biota sedang

$\mathrm{H}^{\prime}>3$ = stabilitas komunitas biota tinggi Tingkat kekayaan spesies dapat dihitung melalui rumus yang ditemukan oleh Margalef (1958) dalam Swasta (2003) sebagai berikut:

$$
\mathrm{R}=\left(\frac{\mathrm{s}-1}{\ln \mathrm{N}}\right)
$$

Keterangan :

$\mathrm{R}=$ Indeks kekayaan spesies

$\mathrm{S}=$ Jumlah spesies dalam komunitas

$\mathrm{N}=$ Total individu dalamkomunitas

Dengan kriteria indeks kekayaan jenis yang digolongkan dalam 3 kategori berdasarkan odum (1994), yaitu: Jika nilai $R<3.5$ maka kekayaan jenis yang tergolong rendah, jika nilai $R=3.5-5.0$ maka kekayaan jenis tergolong sedang, dan jika nilai $R>5.0$ maka kekayaan jenis tergolong tinggi. 
Tingkat kemerataan spesies merupakan gambaran sebaran individu dalam komunitas dan dapat dihitungdengan memakai rumus tingkat kemerataan yang ditemukan oleh Pielou dalam Swasta (2003). Adapun rumusnya sebagai berikut.

$$
\mathrm{E}=\left(\frac{\mathrm{H}^{\prime}}{\ln s}\right)
$$

Keterangan :

$\mathrm{E} \quad=$ Indeks kemerataan spesies

$\mathrm{H}^{\prime} \quad=$ Indeks diversitas

$\mathrm{S}=$ Jumlah spesies di dalam komunitas

$\mathrm{S}=$ Jumlah spesies di dalam komunitas

Dominansi jenis tertentu diperairandapatdigunakanindeksdomina nsidariSimpsondenganpersamaan berikut:

$$
C=\sum\left(\frac{n i}{N}\right)^{2}
$$

Keterangan:

$\mathrm{C} \quad=$ Indeks Dominansi

ni =Cacah individu spesies ke-i

$\mathrm{N}=$ Total individu dalam komunitas

Dengan Indeks Dominansi antara $0-1$

$C=0$, berarti tidak terdapat spesies yang mendominasi spesies lainnya atau strukturkomunitas dalam keadaanstabil
$C=1$, berarti terdapat spesies yang mendominasi spesies lainnya atau struktur komunitasnya labil, karena terjadi tekanan ekologis

Untuk nilai kemelimpahan relatif dapat dihitung dengan rumus berikut:

$$
\mathrm{KR}=\frac{\text { Cacah Individu Spesies } \mathrm{A}}{\text { Total Individu Komunitas } \mathrm{x}} \times 100 \%
$$

Kemudian untuk membandingkan indeks keanekaragaman pada masingmasing ekosistem digunakan uji $t$ ekologis. Indeks keanekaragaman dihitung untuk mencad nilai thitung. Selanjutnya dicari nilai derajat bebas dengan persamaan berikut:

$$
D B=\frac{\left(\operatorname{Var} H_{1}^{\prime}+\operatorname{Var} H_{1}^{\prime}\right)^{2}}{\left(\operatorname{Var} H_{1}^{\prime}\right)^{2} / N_{1}+\left(\operatorname{Var} H_{1}^{\prime}\right)^{2} / N_{2}}
$$

Dengan menghitung derajat bebas kits dapat mengetahui nilai thitung Kemudian dilihat perbandingan antara ekosistem padang lamun, terumbu karang dan mangrove dengan indikator jika nilaithitung $>t_{\text {tabel }}$ maka terdapat perbedaan keanekaragam fitoplankton. Jika nilai $t_{\text {hitung }}>t_{\text {tabelmaka tidak terdapat }}$ perbedaan keanekaragam fitoplankton. Untuk mengetahui perbandingan kemelimpahan fitoplankton antara ekosistem satu dengan lainnya dapat dianalisis menggunakan Anava yang dibantu dengan program SPSS versi 16.0. 


\section{HASIL DAN PEMBAHASAN}

Hasil penelitian dapat dilihat dalam bentuk gambar dan tabel berikut.

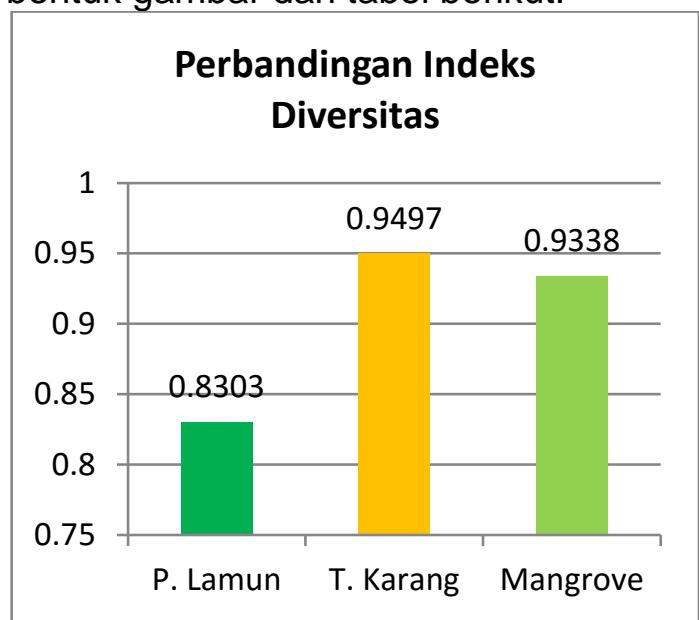

Gambar 1. Perbandingan Indeks Diversitas ( $\mathrm{H}^{\prime}$ ) pada Ekosistem Padang Lamun, Terumbu Karang dan Mangrove

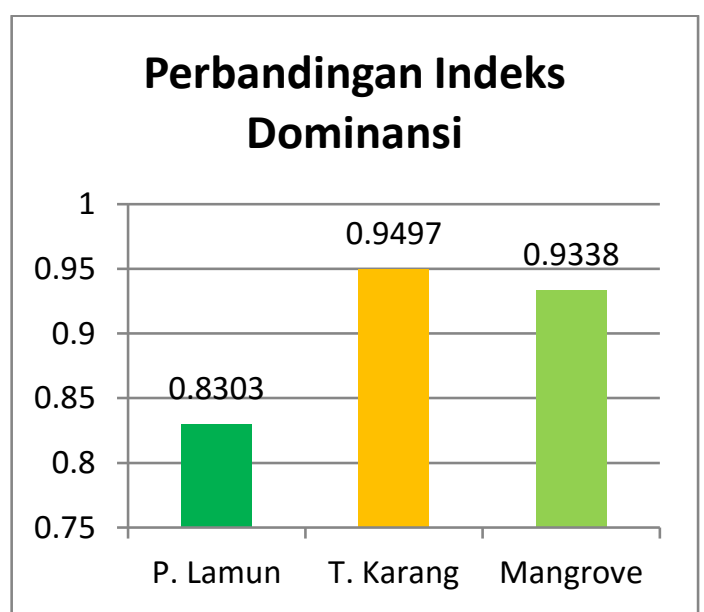

Gambar 2. Perbandingan Indeks Dominansi (C) pada Ekosistem Padang Lamun, Terumbu Karang dan Mangrove

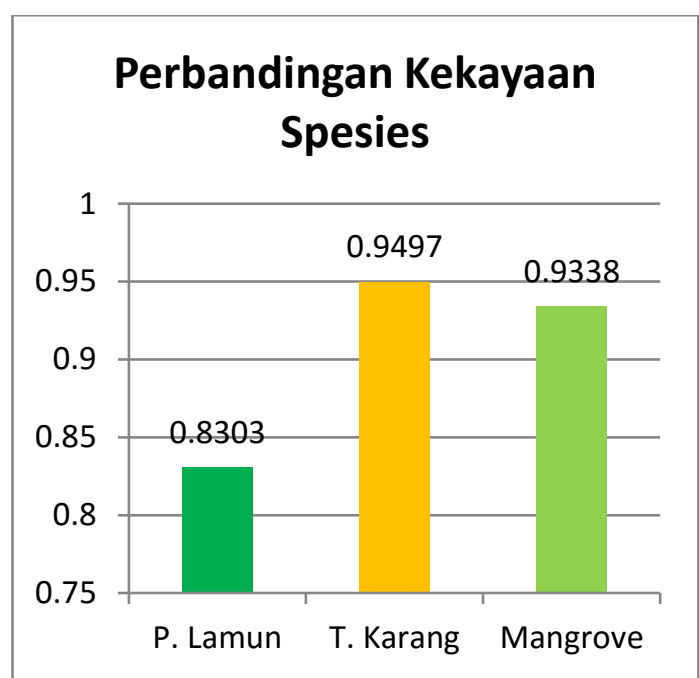

Gambar 3. Perbandingan Kekayaan Spesies (R) pada Ekosistem Padang Lamun, Terumbu Karang dan Mangrove

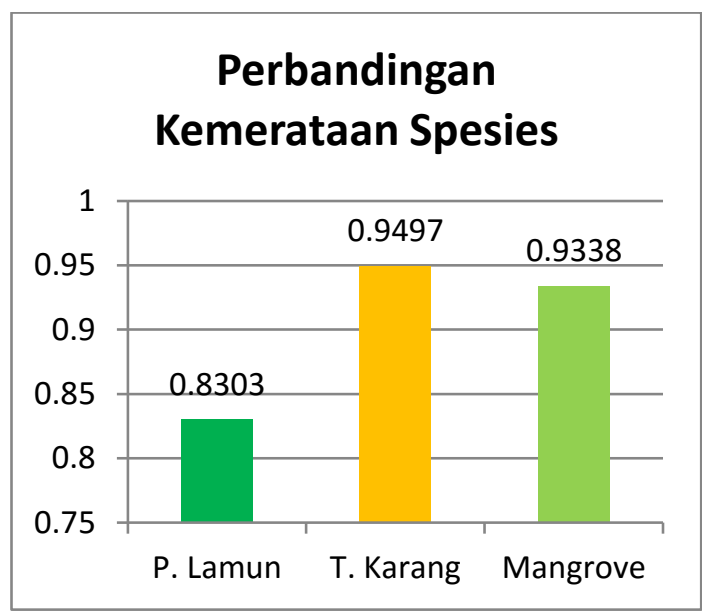

Gambar 4. Perbandingan Tingkat Kemerataan Spesies (E) pada Ekosistem Padang Lamun, Terumbu Karang dan Mangrove

Kemudian berdasarkan analisis yang dilakukan menggunakan uji $t$ (t test), maka diperoleh nilai $t_{\text {hitung }}$ dan tabelyang dirangkum dalam matriks berikut ini. 
Tabel 1. Rangkuman Hasil Uji t Keanekaragaman Fitoplankton Pada Ketiga Ekosistem

\begin{tabular}{|c|c|c|c|}
\hline & Padang Lamun & Terumbu Karang & Mangrove \\
\hline $\begin{array}{l}\text { Padang } \\
\text { Lamun }\end{array}$ & & & \\
\hline $\begin{array}{l}\text { Terumbu } \\
\text { Karang }\end{array}$ & $\begin{array}{l}t_{\text {hitung }}=15,0110 \\
t_{\text {tabel }}=1,9600 \\
\text { berbeda signifikan }\end{array}$ & & \\
\hline Mangrove & $\begin{array}{l}t_{\text {hitung }}=5,7917 \\
t_{\text {tabel }}=1,9600 \\
\text { berbeda signifikan }\end{array}$ & $\begin{array}{l}t_{\text {hitung }}=21,1395 \\
t_{\text {tabel }}=1,9600 \\
\text { berbeda } \\
\text { signifikan }\end{array}$ & \\
\hline
\end{tabular}

Dengan analisis menggunakan program SPSS maka akan muncul indeks kemelimpahan fitoplankton yang dibandingkan antara ekosistem padanglamun dan terumbu karang, terumbu karang dan mangrove, serta padang lamun dan mangrove yang dirangkum dalam tabel berikut.

Tabel 2. Rangkuman Hasil Analisis Kemelimpahan Fitoplankton Pada Ketiga Ekosistem

\begin{tabular}{|c|c|c|c|c|c|c|}
\hline $\begin{array}{l}\text { Perbandingan } \\
\text { kemelimpahan } \\
\text { Fitoplankton }\end{array}$ & $\mathrm{db}$ & Nilai $\alpha$ & $\begin{array}{c}\text { Taraf } \\
\text { Signifikansi }\end{array}$ & $F_{\text {hitung }}$ & tabel & Simpulan \\
\hline $\begin{array}{c}\text { Padang Lamun } \\
\text { Terumbu karang } \\
\text { Mangrove }\end{array}$ & $\begin{array}{c}2 \\
42\end{array}$ & 0,000 & $5 \%$ & $2,84^{2}$ & ,23 & $\begin{array}{l}\text { Ada perbedaan } \\
\text { kemelimpahan }\end{array}$ \\
\hline
\end{tabular}

Dari identifikasi yang telah penulis lakukan tampak beberapa spesies fitoplankton yang menonjol pada ekosistem padang lamun, terumbu karang dan mangrove. Pada ekosistem padang lamun spesies fitoplankton yang paling banyak ditemukan adalah Guinardia balvyana dengan jumlah 321 , Tintinnopsis beroidea dengan jumlah 283, Tintinnopsislobiancoi dengan jumlah 169, Rhizosolenia styliformis dengan jumlah 196, dan Coscinodiscus excentricus dengan jumlah 188. Pada ekosistem terumbu karang beberapa spesies yang menonjol yakni Cocconeis scutelum dengan jumlah 149,
Coscinodiscus excentricus dengan jumlah 107, Guinardia balvyana dengan jumlah 77 , Triceratium alternans dengan jumlah 77, dan Licmophora flabellata dengan jumlah 74.Sedangkan pada ekosistem mangrove ditemukan spesies fitoplankton yang menonjol antara lain Triceratium alternaus dengan jumlah 134, Cocconeis scutelum dengan jumlah 129, Coscinodiscus excentricus dengan jumlah 121, dan Navicula elegana dengan jumlah 100.

Jika dilihat dengan cermat dari ketiga ekosistem tersebut, terdapat beberapa spesies fitoplankton yang menonjol dan ditemukan tidak hanya 
pada satu ekosistem saja yaitu Guinardiablavyana, Tintinnopsis beroidea, Coscinodiscus excentricus, Tintinnopsis lobiancoi, Biddulphiasurita, Triceratiumalternans, Leptocylindris danicus, Ceratium extensum dan Melosira nommuloides. Secara garis besar spesies yang menonjol dan sering dijumpai tersebut tergolong ke dalam golongan Diatom. Berdasarkan kajian pustaka, golongan Diatom merupakan golongan yang paling umum dan banyak ditemukan di laut. Sehingga menonjoinya spesies-spesies tersebut merupakan hal yang normal karena struktur selnya yangsederhana sehingga memudahkan golongan ini dalam melakukan adaptasi terhadap lingkungannya. Oleh karena itu golongan diatom ditemukan secara melimpah di semua bagian lautan.

Adaptasi diatom secara morfologi dilakukan dengan menyesuaikan bentuk tubuhnya menyerupai kantong (seperti Coscinodiscus excentricus), menyerupai jarum (seperti Ceratium extensum) dan menyerupai pita. Hal ini dilakukan sebagai usaha untuk melawan gravitasi bumi sehingga memudahkan plankton untuk mengapung di permukaan air dan proses tenggelamnya menjadi terhambat. Pada sel diatom biasanya dijumpai dinding sel yang terbuat dari silika (seperti pada Coscinodiscus excentricus, Navicula elegana dan Cocconeisscutelum), struktur ini menjadi karakteristik utama yang membedakan golongan diatom dengan golongan fitoplankton lainnya. Disamping itu, diatom juga melakukan adaptasi fisiologis dengan cara menimbun minyak yang ringan di dalam selnya sebagai salah satu hasil dari fotosintesis. Minyak ini tidak larut dalam air, dan membantu diatom mengurangi berat jenis selnya. Hal iniakan mendukung kemampuan diatom untuk mengapung secara bebas di permukaan air.

Berdasarkan hasil perhitungan yang telah penulis lakukan, didapatkan nilai indeks keanekaragaman (H') fitoplankton pada ekosistem padang lamun sebesar 2,6390, pada ekosistem terumbu karang sebesar 3,2915 dan pada ekosistem mangrove sebesar 2,7970. Dengan nilai tersebut dapat dikatakan bahwa pada ekosistem padang lamun dan mangrove kondisi komunitas biotanya sedang atau dengan kata lain kualitas air pada ekosistem tersebut sedang (belum terdapat indikasi pencemaran). Pada ekosistem padang lamun terdapat dermaga tempat berlabuhnya kapal (boat) yang merupakan sarana penyebrangan. Terdapat kemungkinan bahwa penggunanaan kapal-kapal bermotor ini memberikan pengaruh pada kondisi perairan. Di kawasan mangrove terdapat pula dermaga sebagai tempat kapal berlabuh dan teramati juga banyak terdapat sampah diseputaran area ini, hal ini dikhawatirkan memberikan dampak buruk bagi keseimbangan lingkungan hutan mangrove.

Pada ekosistem padang lamun kemelimpahan relatif teringgi adalah Guinardia blavyan sebesar 16,4363\%, padaekosistemterumbukarang Cocconei s scutelum sebesar $10,2901 \%$ dan pada ekosistem mangrove Triceratium altemans sebesar $11,5917 \%$. Spesies yang menonjol pada masing-masing ekosistem tersebut merupakan golongan diotom yang keberadaannya ditemukan paling banyak di lautan. Jadi 
nilai kemelimpahan relatif masingmasing spesiesies di atas masih dianggap wajar.

Berdasarkan perhitungan nilai indeks dominansi fitoplankton pada ekosistem padang lamun adalah 0,0967, pada ekosistem terumbu karang 0,0438 dan pada ekosistem mangrove 0,0707. Nilai-nilai tersebut menyatakan bahwa tidak ada salah satu spesies fitoplankton yang mendominasi speseis fitoplankton lainnya pada ketiga ekosistem. Artinya struktur komunitas pada masing-masing ekosistem dalam keadaan stabil.

Nilai tingkat kekayaan spesies pada ekosistem padang lamun adalah 3,0350 , pada ekosistem terumbu karang 4,2600 dan pada ekosistem mangrove sebesar 2,6940. Nilai-nilai ini menunjukkan bahwa kekayaan jenis fitoplankton pada ekosistem padang lamun dan mangrove termasuk kategori rendah, sedangkan kekayaan jenis fitoplankton pada ekosistem terumbu karang tergolong sedang.

Kemerataan spesies fitoplankton pada ekosistem padang lamun menunjukkan nilai 0,8303 , ekosistem terumbu karang sebesar 0,9497 dan ekosistem mangrove sebesar 0,9338. Berdasarkan kriteria tingkat kemerataan spesies maka kemerataan spesies fitoplankton pada ketiga ekosistem tergolong tinggi. Hal ini sejalan dengan pendapat Hasrun, dkk (2013) yang menyatakan bila indeks kemerataan mendekati 1, menunjukkan bahwa penyebaran individu dalam satu spesies tidak ada perbedaan mencolok.

Pada

perbandingan keanekaragaman fitoplankton antara ekosistem padang lamun dan terumbu karang, nilai thitug adalah 15,0110 dan $t_{\text {tabel }}$ adalah 1,960 yang berarti $15,0110>$
1,9600. Sesuai dengan kriteria yang ada maka terdapat perbedaan keanekaragaman fitoplankton yang signifikan antara ekosistem padang lamun dan terumbu karang. Selanjutnya adalah perbandingan keanekaragaman fitoplankton antara ekosistem terumbu karang dan mangrove, nilai $t_{\text {hitung }}$ adalah 21,1395 dan $t_{\text {tabel }}$ adalah 1,9600 yang berarti 21,1395 > 1,9600. Maka berdasarkan kriteria dapat dinyatakan bahwaterdapat,perbedaan

keanekaragaman fitoplankton yang signifikan antara ekosistem terumbu karang dan mangrove. Perbandingan yang terakhir adalah antara ekosistem padang lamun dan mangrove, dimana nilai thitung adalah 5,7917 dan tabel adalah 1,9600 yang berarti 5,7917 > 1,9600. Jadi dapat dinyatakan bahwa terdapat perbedaan keanekaragaman fitoplankton yang signifikan antara ekosistem padang lamun dan mangrove.

Terdapatperbedaan

kemelimpahanfitoplanktonantara ekosistem padang lamun, terumbu karang dan mangrove. Untuk analisa perbandingan kemelimpahan dilakukan dengan anava, sehingga hasil perhitungan menghasilkan $F_{\text {hitung }}$ yang kemudian dibandingkan dengan $F_{\text {tabel }}$ berdasarkan derajat bebas. Apabila $F_{\text {hitung }}>F_{\text {tabel }}$ maka artinya terdapat perbedaan kemelimpahan fitoplankton antara masing-masing ekosistem. Namun jika $F_{\text {hitung }}>F_{\text {tabel }}$ berarti tidak ada perbedaan kemelimpahan fitoplanktonantaramasing-masing ekosistem. Berdasarkan data pada tabel

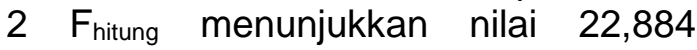
sedangkan $F_{\text {tabel }}$ sebesar 3,23. Nilai ini sesuai dengan kriteria pertama yaitu $22,884>3,23$. Hal ini didukung pula 
dengan hasil perbandingan nilai signifikansi. Telah ditentukan bahwa taraf signifikansi dalam penelitian ini adalah $5 \%$ atau 0,05. Berdasarkan analisis menggunakan anava, maka didapat nilai signifikansi kemelimpahannya adalah 0,000. Jika nilai signifikansi kemelimpahan lebih kecil dari taraf signifikansi $(0,000<0,05)$ maka hal ini mendukung hasil perbandingan nilai $F$ diatas. Jadi dapat disimpulkan bahwa terdapat perbedaan kemelimpahan fitoplankton yang signifikan antara ekosistem padang lamun, terumbu karang dan mangrove.

Dari hasil perhitungan keanekaragaman dan kemelimpahan fitoplankton di atas terdapat beberapafaktor yang mempengaruhi perbedaan tersebut. Faktor-faktor tersebut antara lain: 1) faktor fisika dan kimia perairannya, 2) aktivitas manusia di sekitar ekosistem, dan 3) kandungan unsur hara pada masing-masing ekosistem.

Selain melakukan pengamatan terhadap faktor biotik, perlu juga dilakukan pengamatan faktor abiotik perairan. Dengan mempelajari aspek saling ketergantungan antara organisme dengan faktor abiotik akan diperoleh gambaran tentang kualitas perairan. Berdasarkan pengukuran terhadap kondisi perairan pada ekosistem padang lamun, terumbu karang dan mangrove di kawasan Taman Nasional Bali Barat terdapat faktor-faktor berikut.

Tinggi rendahnya suhu suatu badan perairan sangat mempengaruhi kehidupan organisme air, termasuk plankton. Suhu air di permukaan laut biasanya dipengaruhi oleh lintang. Pada saat pengukuran parameter lingkungan di lokasi penelitian didapatkan hasil bahwa suhu pada ekosistem padang lamun berkisar antara $27-28{ }^{\circ} \mathrm{C}$, sedangkan pada ekosistem terumbu karang antara $26-27{ }^{\circ} \mathrm{C}$ dan pada ekosistem mangrove antara $27-28^{\circ} \mathrm{C}$. Hasil pengukuran suhu pada ketiga ekosistem tersebut masih tergolong suhu optimum yang memungkinkan bagi fitoplankton untuk hidup dan berkembang dengan baik. Sehingga fitoplankton dapat ditemukan secara melimpah pada perairan di ekosistem padang lamun, terumbu karang dan mangrove. Selain itu waktu pengukuran juga mempengaruhi hasil pengukuran air. Pengukuran dilakukan pada sore menjelang malam hari saat matahari sudah terbenam. Oleh karena itu ratarata suhu yang didapat ketika pengukuran mungkin akan sedikit berbeda dengan suhu air pada siang hari.

Salinitas merupakan takaran bagi keasinan air laut. Salinitas air pada ekosistem padang lamun berkisar antara 30 - 31 ppt, kemudian salinitas air pada ekosistem terumbu karang antara 30 - 32 ppt dan salinitas air pada ekosistem mangrove antara 28 - 29 ppt. Berdasarkan penelitian yang dilakukan Yuliana, dkk (2012) salinitas optimum bagifitoplankton antara 28 hingga 33 ppt dan faktor salinitas ini bukan merupakan faktor pembatas. Sehingga kisaran salinitas pada ketiga ekosistem tersebut masih terbilang optimum bagi kehidupan komunitas fitoplanktonnya. Secara alami kandungan garam terlarut dalam air dapat meningkat apabila populasi fitoplankton menurun. Hal ini dapat terjadi karena melalui aktivitas respirasi dari hewan dan bakteri air akan meningkatkan proses mineralisasi yang menyebabkan kadar garam air 
meningkat. Salinitas juga dapat dipengaruhi oleh pasang surut, curah hujan,penguapan,presipitasidan topografi suatu perairan.

NilaipHmenggambarkanintensitas keasaman dan kebasaan suatuperairan yang ditunjukkan oleh keberadaan ion hidrogen. Sebagian besar biota akuatik sensitif terhadap adanya perubahan $\mathrm{pH}$ dan dapat bertahan hidup pada $\mathrm{pH}$ sekitar 7 - 8,5. Bila $\mathrm{pH}$ suatu perairan terlalu tinggi atau terlalu rendah, maka akan mengakibatkan kematian bagi organisme yang menghuni perairan tersebut karena sistem metabolismenya terganggu. Pada ekosistem padang lamun kisaran $\mathrm{pH}$ antara $8-8,5$. Pada ekosistem terumbu karang kisaran $\mathrm{pH}$ antara 7,8 -8,5 dan pada ekosistem mangrove antara 7,8 - 8,1. Nilai $\mathrm{pH}$ air pada kawasan ekosistem padang lamun, terumbu karang dan mangrove tergolong $\mathrm{pH}$ yang optimum bagi keberlangsungan hidup fitoplankton.

Turbiditas (kekeruhan) merupakan salah satu indikator pengujian kualitas air. Tingkat kekeruhan air dalam suatu ekosistem dipengaruhi oleh kandungan bahan orgaik dan anorganiknya, dimana kandungan ini nantinya akan mempengaruhi kehidupan organisme yang menempati wilayah tersebut. Menurut Fitri (2011) kekeruhan air disebabkan oleh tingginya kandungan bahan organik dan anorganik tersuspensi seperti lumpur, pasir halus, maupun bahan organik dan juga dapat disebabkan oleh bahan-bahan tersuspensi berupa lapisan permukaan tanah. Bagi fitoplankton, tingkat kekeruhan akan mempengaruhi intensitas cahaya matahari yang masuk ke dalam perairan dan dapat menghambat berlangsungnya proses fotosintesis untuk menghasilkanoksigen. Pada ekosistem padang lamun kisaran turbiditasnya antara $11-12 \mathrm{mg} / \mathrm{lt}$, pada ekosistem terumbu karang antara $9-10$ $\mathrm{mg} / \mathrm{lt}$ dan pada ekosistem mangrove antara 11 - $13 \mathrm{mg} / \mathrm{lt}$. Secara umum batas turbiditas yang diperbolehkan dalam suatu perairan adalah kurang dari $30 \mathrm{mg} / \mathrm{lt}$. Jadi kisaran turbiditas pada ketiga ekosistem masih tergolong memenuhi syarat bagi keberlangsungan hidup fitoplankton. Dari tiga ekosistem, turbiditas pada ekosistem mangrove memiliki angka tertinggi.

\section{SIMPULAN}

Berdasarkan hasil pembahasan di atas dapat dismpulkan sebagai berikut. Komposisi spesies fitoplankton yang berhasil diidentifikasi pada ekosistem padang lamun sebanyak 24 jenis, pada ekosistem terumbu karang 32 jenis dan ekosistem mangrove sebanyak 20 jenis. Indeks keanekaragaman spesies fitoplankton pada ekosistem terumbu karang tergolong tinggi yakni bernilai 3,2915 sedangkan pada ekosistem padang lamun dan mangrove tergolong sedang dengan nilai 2,6390 dan 2,7970. Kemelimpahan relatif tertinggi pada ekosistem padang lamun adalah spesies Guinardia blavyana (16,4363\%), pada ekosistem terumbu karang adalah spesies Cocconeis scutelum $(10,2901 \%)$ dan pada ekosistem mangrove adalah spesies Triceratium altemans $\quad(11,5917 \%)$. Terdapat perbedaan keanekaragaman fitoplankton antara ekosistem padang lamun, terumbu karang dan mangrove. Terdapat perbedaan kemelimpahan fitoplankton antara ekosistem padang lamun, terumbu karang dan mangrove 
Perlupenelitianlebihlanjutdengan cakupan yang lebih luas dengan maksud perlu juga nantinya diteliti mengenai keberadaan komunitas zooplanktonnya karena di perairan fito maupun zooplankton ada secara bersama-sama.

\section{DAFTAR PUSTAKA}

Asriyana., $\quad$ Yuliana. 2012. ProduktivitasPerairan. Jakarta: Bumi Aksara

Dawes, C.J. 1987. The Biology of Commercial Important Tropical Marine Algae dalam Bird. K.T. dan P.H. Benson (ed.) Seaweed Cultivation For Renewable Resources. Elsevier. Amsterdam.

Fachrul, Melati Frianita. 2007. MetodeSampling Bioekologi. Jakarta:Bumi Aksara
Nybakken, 1998. BiologiLaut. SuatuPendekatanEkologis. Gramedia, Jakarta

Odum, E.P. 1994. Dasar-dasar Ekologi (terjemahan). Yogyakarta: Gadjah Mada University

Swasta, Ida Bagus Jelantik. 2003. Diktat Ekologi Hewan. Singaraja: IKIP Negeri Singaraja

Swasta, Ida Bagus Jelantik. 2010. Bioekologi Perairan Laut dan Payau. Jogja: Jogja Mediautama

Odum, E.P. 1971. Fundamental of Ecology. W.B. Sounders Company. Philadelphia. 574 hal.

Perry, R. 2003. A Guide to the Marine Phytoplankton of Southern California.Dipublikasikan: www. msc.Ucla/oceanglobe/pdf/guide.2 $3 \mathrm{hlm} .25$ Mei 2013.

RomimohtartodanJuwana, 2001.BiologiLaut.

P3OLIPI, Jakarta. 